\title{
Recent Monetary Developments and Controversies
}

ECONOMIC developments during the past year were distinctly unkind to the nostrums of monetary economists. The phenomenal growth of negotiable orders of withdrawal (NOW accounts) and money market mutual fund shares and, more recently, the emergence of retail sweep accounts reopened questions about the stability of money demand and the value of monetary aggregates as intermediate targets. The stubborn persistence of high interest rates in the face of unwinding inflation and deepening recession puzzled many economists. Observing the continued volatility of both interest rates and money, some critics of the Federal Reserve's new operating procedures concluded that short-run monetary control was receiving too little attention while other critics concluded just the reverse.

This paper reviews monetary developments in the past year and their bearing on these controversies. The first section examines whether

I am indebted to numerous staff members of the Board of Governors of the Federal Reserve System for the germination of many of the ideas expressed in this paper; I have benefited greatly from many discussions with them over the years. For more concrete contributions to this paper, I thank Stephen H. Axilrod, Flint Brayton, Edward C. Ettin, Richard Field, Bonnie Garrett, Henry Hayssen, David Jones, Kenneth J. Kopecky, Mary McLaughlin, Edward K. Offenbacher, Richard D. Porter, Thomas D. Simpson, David Wilcox, and John R. Williams of the Board staff and Ralph C. Bryant and members of the Brookings panel. The views expressed in this paper are solely those of the author and do not necessarily reflect those of the Board of Governors of the Federal Reserve System or other members of its staff. 
financial innovations have perceptibly altered the velocity of various monetary aggregates, with special emphasis on the experience over 1981 as a whole. The second section reviews recent quarterly data on relations among money demand, short-term interest rates, real income, and prices and attempts to sort out the sources both of the continuance of high short-term interest rates and of recent intrayearly swings in money demand. A final section of the paper reflects on the meaning of erratic short-run money growth and its implications for how precisely to control monetary aggregates and for the usefulness of intermediate monetary targets.

\section{Financial Innovations and Velocity Behavior}

Contrasting views have recently been advanced on the impact of financial innovations on the relations between the monetary aggregates and broader economic conditions. Some commentators argue that the current wave of innovations is significantly affecting these relations and in the long run may even threaten the viability of intermediate moneystock targets. ${ }^{1}$ Others take an opposing position, contending that M1 velocity, at least, has not departed much in recent years from historical patterns. ${ }^{2}$

In an effort to bring empirical evidence to bear on these issues, this section analyzes recent growth rates of the velocity of monetary aggregates in the context of longer-term trends. Table 1 breaks the period since 1960 into three seven-year subperiods. The third one conveniently begins with the previous episode of financial innovations in the mid1970s, when adoption of new corporate cash-management devices intensified. ${ }^{3}$

1. See, for example, Anthony M. Solomon, president, Federal Reserve Bank of New York, remarks before the joint luncheon of the American Economic and American Finance Association, December 28, 1981, and Frank E. Morris, president, Federal Reserve Bank of Boston, "Do the Monetary Aggregates Have a Future as Targets of Federal Reserve Policy?"' The New England Economic Review (March-April 1982), pp. 5-14.

2. Beryl W. Sprinkel, under secretary of the treasury for monetary affairs, "Statement" before the Subcommittee on Domestic Monetary Policy of the Committee on Banking, Finance and Urban Affairs, March 3, 1982, pp. 3-4, and Economic Report of the President, February 1982, page 63.

3. See Stephen M. Goldfeld, "The Case of the Missing Money," BPEA, 3:1976, pp. 683-730; Richard D. Porter, Thomas D. Simpson, and Eileen Mauskopf, "Financial 
Table 1. Average Percent Changes of Various Velocity Measures, Three-Month Treasury Bill Rate, and Real GNPa

Percent

\begin{tabular}{|c|c|c|c|c|c|c|}
\hline \multirow[b]{2}{*}{ Period and measure } & \multicolumn{4}{|c|}{ Velocity measure } & \multirow[b]{2}{*}{$\begin{array}{l}\text { Three- } \\
\text { month } \\
\text { Treasury } \\
\text { bill rate } \\
\quad \text { (5) }\end{array}$} & \multirow[b]{2}{*}{$\begin{array}{c}\text { Real } \\
\text { GNP } \\
\text { (6) }\end{array}$} \\
\hline & $\begin{array}{l}M 1 \\
(1)\end{array}$ & $\begin{array}{c}\text { "Old"' } \\
\text { M1 } \\
(2)\end{array}$ & $\begin{array}{c}\text { "Shift- } \\
\text { ad- } \\
\text { justed", } \\
\text { M1 } \\
\text { (3) }\end{array}$ & $\begin{array}{l}M 2 \\
(4)\end{array}$ & & \\
\hline \multicolumn{7}{|l|}{$1961-67$} \\
\hline Mean & 3.3 & 3.3 & 3.3 & -0.4 & 11.4 & 5.0 \\
\hline Standard deviation & 2.2 & 2.2 & 2.2 & 2.3 & 10.9 & 1.5 \\
\hline \multicolumn{7}{|l|}{$1968-74$} \\
\hline Mean & 2.6 & 2.6 & 2.6 & 0.5 & 9.8 & 2.7 \\
\hline Standard deviation & 1.6 & 1.7 & 1.6 & 2.5 & 26.7 & 3.1 \\
\hline \multicolumn{7}{|l|}{$1975-81$} \\
\hline Mean & 3.7 & 6.5 & 4.4 & 0.3 & 9.9 & 2.9 \\
\hline Standard deviation & 1.3 & 4.8 & 1.6 & 2.7 & 25.6 & 2.2 \\
\hline \multicolumn{7}{|l|}{ Memoranda } \\
\hline 1975 & 4.8 & 4.9 & 4.9 & -1.9 & -23.6 & 2.2 \\
\hline 1976 & 2.9 & 3.5 & 3.1 & -3.8 & -16.9 & 4.4 \\
\hline 1977 & 3.7 & 4.1 & 3.8 & 0.7 & 30.7 & 5.8 \\
\hline 1978 & 5.5 & 6.3 & 5.8 & 5.6 & 40.3 & 5.3 \\
\hline 1979 & 2.3 & 4.8 & 3.1 & 1.4 & 38.2 & 1.7 \\
\hline 1980 & 1.9 & 4.1 & 2.6 & 0.2 & 14.9 & -0.3 \\
\hline 1981 & 4.5 & 18.1 & 7.3 & 0.2 & -13.7 & 0.9 \\
\hline
\end{tabular}

Sources: Board of Governors of the Federal Reserve System for monetary stock and Treasury bills rate data. Nominal and real GNP are from the national income and product accounts.

a. Fourth quarter to fourth quarter.

b. Velocity is the ratio of nominal GNP to a monetary aggregate. The several velocity growth rates shown here correspond to different monetary aggregates. M1 is defined as currency outside the Treasury, Federal Reserve banks, and the vaults of commercial banks; traveler's checks of nonbank issuers; demand deposits at all commercial banks other than those due to domestic banks; the U.S. government, and foreign banks and official institutions minus cash items in the process of collection and Federal Reserve float; and other checkable deposits (OCD) consisting of negotiable orders of withdrawal (NOW), automatic transfer service (ATS), and credit union share draft (CUSD) accounts, and demand deposits at mutual savings banks. "Old" M1 is M1 minus other checkable deposits. Shiftadjusted M1 is M1 minus that portion of OCD estimated to have shifted from non-M1 sources; this estimate is onethird of OCD inflows from 1975 through 1980. For 1981, growth of the Board's "shift-adjusted" M1 is used, with the fraction of net OCD inflows in excess of trend coming from non-M1 sources estimated to be $221 / 2$ percent in January and $271 / 2$ percent in the remaining months of the year. M2 is defined as M1 plus savings and small denomination time deposits at all depository institutions, overnight repurchase agreements at commercial banks, overnight Eurodollars held by U.S. residents other than banks at Caribbean branches of member banks, and balances of money market mutual funds (general purpose and broker-dealer).

c. Secondary market.

Innovation and the Monetary Aggregates," BPEA, 1:1979, pp. 213-29; Thomas D. Simpson and Richard D. Porter, "Some Issues Involving the Definition and Interpretation of the Monetary Aggregates," in Federal Reserve Bank of Boston, Controlling Monetary Aggregates III, Conference Series 23 (FRBB, October 1980), pp. 161-234; and Donald D. Hester, "Innovations and Monetary Control," BPEA, 1:1981, pp. 141-89. 


\section{CHANGING CONCEPTS OF M1 VELOCITY}

Annual velocity growth of M1 as currently measured is shown in column 1. The trend growth of this measure rose from 2.6 percent a year in the middle subperiod to 3.7 percent since 1974, despite similar average percent changes in Treasury bill rates and real income (last two columns). ${ }^{4}$ This increase in trend growth of about 1 percentage point is not enormous, although it implies that by 1981 the level of M1 needed to support actual nominal GNP would be about 7 percent (or $\$ 31.5$ billion) lower than would have been predicted on the basis of the average annual velocity growth of 2.6 percent that prevailed during 1968-74.

However, the Federal Reserve was not targeting this measure of M1 until the monetary aggregates were redefined in February 1980. At that time the definition of narrow money was expanded to include other checkable deposits (OCDs) - primarily composed of NOW accounts, ATS accounts (automatic transfer service), and credit union share drafts-and this aggregate was transitionally relabeled M1B. The annual velocity growth of M1 excluding OCDs, essentially old M1, accelerated markedly during the last seven years, particularly in 1981, as shown in column 2. The Federal Reserve, in establishing annual ranges for old M1 before 1980 and for M1A and M1B (or its equivalent, new M1) thereafter, attempted to take account of the effects of expansion in OCDs. The evolution of OCDs thus required the Federal Reserve to keep monetary targets and definitions abreast of developments.

This point only initiates a complete analysis of the effects of financial innovations on M1 velocity behavior. The expansion of ATS and NOW accounts, which are presently included in M1, has been boosted by shifts from savings deposits and other non-M1 sources, thereby raising the growth of M1 demand above what it would otherwise have been. The implication is that the velocity of actual M1 has grown more slowly than would have been the case if OCDs had never been introduced. Owing to the year-end 1980 introduction of nationwide NOWs, this effect was

4. In standard M1 demand functions the partial elasticity with respect to interest rates is negative and-consistent with an inventory theory of money demand-the elasticity with respect to real income is positive but less than unity. Thus increases in both raise M1 velocity, other things being equal. 
particularly pronounced last year, when the velocity of actual M1 increased 23/4 percentage points more slowly than the velocity of an M1 measure that attempts to abstract from the effects of NOWs, shown in column 3. The latter "shift-adjusted" measure removes from M1 an estimate of the funds switched to NOW accounts from non-M1 sources in 1981, on the grounds that such inflows distorted the demand for M1 relative to its historical determinants. ${ }^{5}$ It is estimated that $\$ 12 \frac{1}{4}$ billion shifted from non-M1 sources to OCDs during that year. ${ }^{6}$

This adjusted concept in earlier years is shown in column 3 by the velocity growth of an unofficial estimate of shift-adjusted M1, which is constructed by subtracting from M1 an estimate of the fraction of inflows to OCDs from non-M1 sources in those years. The growth of this adjusted M1 velocity was $13 / 4$ percentage points faster, on average, in the third subperiod than in the second. By 1981 the velocity growth of this shiftadjusted measure exceeded its trend in the second subperiod by almost $43 / 4$ percentage points. In that year the velocity of actual M1, shown in column 1, grew a bit faster than its historical trend, despite shifts of savings balances into OCDs. These shifts, which reduced velocity, were more than offset by the effect of other unusual factors at work in the opposite direction.

A conventional interest rate response is not one of these other factors increasing velocity. Indeed, in two of the three years in which M1 velocity growth accelerated to above 4 percent, 1975 and 1981, the decline in the Treasury bill rate represented a marked deceleration in its annual rate of change.

What, then, were the other factors? The sources of more rapid velocity growth than expected around the mid-1970s have been examined else-

5. The distortion arose from the higher marginal own rates on transactions balances available on nationwide NOWs and the relatively high minimum balance requirements for these newly offered accounts. The Federal Reserve set a 1981 growth range of $31 / 2$ to 6 percent for this shift-adjusted measure-down from the 4 to $6 \frac{1}{2}$ percent range for actual M1B in 1980.

6. Estimates of the shift in 1981 were derived from surveys of banks and households as well as cross-section regressions of changes in demand or savings deposits on changes in OCD. For further discussion, see David E. Lindsey, "Nonborrowed Reserve Targeting and Monetary Control," forthcoming in Lawrence Meyer, ed., Improving Money Stock Control: Problems, Solutions, and Consequences (Federal Reserve Bank of St. Louis, 1982), and Thomas D. Simpson, John R. Williams and others, "Recent Revisions in the Money Stock: Benchmark, Seasonal Adjustment, and Calculation of Shift-Adjusted M1B," Federal Reserve Bulletin, vol. 67 (July 1981), pp. 539-42. 
where in some detail. ${ }^{7}$ The 1981 experience recently has been scrutinized by Federal Reserve Board staff. In one study, Michael Moran and Donald Kohn estimated that the $\$ 100$ billion expansion of money market mutual fund shares (MMMFs) during 1981 depressed M1 demand and raised M1 velocity by noticeable amounts. ${ }^{8}$ From survey results and data on deposit turnover, they tentatively concluded that, at most, only 4 percent of MMMFs were actively being used for transaction purposes and hence were being substituted directly for M1 balances. This figure implied that growth in MMMFs directly reduced M1 demand over 1981 by only $\$ 4$ billion or about 1 percent. However, the indirect effects, by which the liquidity and the high market return of MMMFs induced a further transfer of funds from M1, were more difficult to gauge. Several ingenious econometric tests-including substituting an MMMF rate for the passbook savings rate in the MIT-Pennsylvania-Social Science Research Council (MPS) quarterly money-demand function and examining the contribution of MMMFs to growth of monetary services as captured by a divisia monetary aggregate-gave somewhat conflicting results. On balance, Moran and Kohn were led to think that the total effect had reduced M1 demand last year somewhere between 1 and 4 percent.

Even after netting out an increase of $2 \frac{1}{2}$ percentage points-the midpoint of Moran and Kohn's estimated range for the overall impact of MMMFs-the growth of shift-adjusted M1 velocity over 1981 remains higher than historical trends. Apportioning the sources of the residual strength is not easy, but an apparent further spread of cash-management techniques to households and medium- and smaller-sized corporations may have played a role.

In any event, the foregoing analysis suggests caution about predicting future stability of actual M1 velocity growth. The recent tendency for unusual factors depressing M1 velocity growth to nearly balance unusual factors raising it may not persist in coming years. In particular, the public's stock adjustment from existing saving balances in M2 to new

7. See note 3 for references.

8. Memorandum, Michael Moran and Donald Kohn to Stephen Axilrod, "The Effects of MMMFs on M1-B: A Review of the Evidence," Board of Governors of the Federal Reserve System, February 1, 1982. 
nationwide NOW accounts-as opposed to placement of funds into existing NOW accounts from new savings out of income or from nonsavings balances in response to interest rate variations-seems to have about run its course. During 1981 the growth of the number of NOW and ATS accounts at an annual rate slowed from an enormous pace through May to 47 percent at commercial banks and 33 percent at sampled savings and loan institutions from May to August. The growth rate of such accounts then fell to 19.4 percent at commercial banks from August to February, and to a similar rate at savings and loans, according to available evidence. This pace has probably decelerated further since then. ${ }^{9}$ In other words, the effects stemming from the introduction of new checkable accounts that have damped actual M1 velocity for the past seven years, and particularly over 1981, are abating. The question then becomes whether the effects of factors acting to bolster M1 velocity also are diminishing or are instead picking up steam. In large part, the answer may depend not only on the prospective advance of MMMFs but also on the speed with which new sweep arrangements are adopted, transferring funds between fixed-balance demand deposits on the one hand and NOW accounts, MMMFs, and repurchase agreements (RPs) on the other. Decisive evidence on this question may well be provided during the next several months.

\section{M2 VELOCITY}

Doubts about the future stability of M1 velocity growth might draw one's attention to broader monetary aggregates. The stable behavior of M2 velocity over each of the last three years, particularly the last two, is a rather striking feature of table 1 . Based on that experience, a prediction of little change in M2 velocity in coming years might be made with some assurance. Indeed, such a prediction is implicitly embodied in the range of forecasts by individual Federal Open Market Committee (FOMC) members of 8 to $10 \frac{1}{2}$ percent for this year's nominal GNP

9. In absolute terms, NOW and ATS accounts at commercial banks numbered 9.2 million in May 1981, 10.3 million three months later (August 1981) and 11.3 million nine months later (February 1982). In light of the falloff of shifting of funds to new NOW accounts from existing demand and savings balances, the Federal Reserve ceased calculating a shift-adjusted M1 in January 1982. 
growth in light of the committee's expectation that in 1982 M2 growth will probably be in the upper part of its 6 to 9 percent range.

One reason M2 velocity has been more stable and predictable in recent years involves the increasing importance of MMMFs and RPs without ceilings and new small-denomination time deposits with yields linked to market rates, such as the six-month money market certificate, the $2 \frac{1}{1} 2$-year small-saver certificate, and the all-saver certificate. The fraction of the nontransaction component of $\mathrm{M} 2$ bearing market-related yields grew from less than 5 percent in early 1978 to over 64 percent by March 1982. As a result, the sensitivity of M2 and its velocity to movements in market interest rates has lessened appreciably.

\section{STABILITY VERSUS CONTROL}

The relative stability and predictability of $\mathrm{M} 2$ velocity also derives in part from the fact that greater weight is given to $\mathrm{M} 1$ in monetary targeting. With M1 more nearly the exogenous monetary aggregate over annual periods, both nominal income and M2 respond in the same direction to unexpected shocks to the demand functions for aggregate spending or M1. The responsiveness of the velocity of M2 to such disturbances thus is muted when $\mathrm{M} 2$ is endogenous compared to the case in which it is determined exogenously and $\mathrm{M} 1$ is endogenous.

This point can be illustrated in a simple IS $=\mathrm{LM}$ framework, where nominal income and the nominal interest rate are represented by $Y$ and $i^{10}$

The aggregate spending (IS) equation is

$$
Y=a-b i+e_{1}
$$

the M1 demand equation is

$$
M I^{D}=d-f i+g Y+e_{2}
$$

10. This analysis is in the spirit of William Poole, "Optimal Choice of Monetary Policy Instruments in a Simple Stochastic Macro Model,"' Quarterly Journal of Economics, vol. 84 (May 1970), pp. 197-216, and is analogous to the examination of reduced-form errors for multipliers relating money to reserves with alternative reserve operating targets appearing in David E. Lindsey and others, "Short-Run Monetary Control: Evidence under the New Operating Procedures" (Board of Governors of the Federal Reserve System, February 1982). 
and the nontransactions component of the $\mathrm{M} 2$ demand equation is

$$
N T^{D}=h-j i+k Y+e_{3} .
$$

M2 is defined as

$$
M 2=M 1+N T .
$$

When $M 1$ is held exogenous at $\overline{M 1}$, the reduced-form expressions for $Y$ and $M 2$ can be decomposed into a predicted value, which is indicated by superscript $p$, and an error term as follows:

$$
Y\left|\overline{M 1}=Y^{p}\right| \overline{M 1}+Y \text { error } \mid \overline{M 1}
$$

where

$$
\begin{gathered}
Y^{p} \mid \overline{M 1}=\frac{a f-b d+b \overline{M I}}{f+b g} \\
Y \text { error } \mid \overline{M 1}=\frac{f e_{1}-b e_{2}}{f+b g} \\
M 2\left|\overline{M I}=M 2^{p}\right| \overline{M I}+M 2 \text { error } \mid \overline{M I}
\end{gathered}
$$

where

$$
\begin{aligned}
& M 2^{p} \mid \overline{M I}= \\
& \quad \frac{h(f+b g)-d(b k+j)+a(f k-j g)+(f+b g+j+k b) \overline{M I}}{f+b g} \\
& M 2 \text { error } \mid \overline{M I}=\frac{(f k-j g) e_{1}-(b k+j) e_{2}+(f+b g) e_{3}}{f+b g} .
\end{aligned}
$$

By contrast, the reduced-form expression for $Y$ when $M 2$ is determined exogenously at $\overline{M 2}$ is

$$
Y\left|\overline{M 2}=Y^{p}\right| \overline{M 2}+Y \text { error } \mid \overline{M 2}
$$

where

$$
\begin{aligned}
Y^{p} \mid \overline{M 2} & =\frac{a(f+j)-b(d+h)+b \overline{M 2}}{(f+j)+b(g+k)} \\
Y \text { error } \mid \overline{M 2} & =\frac{(f+j) e_{1}-b\left(e_{2}+e_{3}\right)}{(f+j)+b(g+k)} .
\end{aligned}
$$

Examination of the error terms in equations 5 and 6 indicates that various disturbances tend to introduce a positive correlation between 
income and $M 2$ when $M 1$ is fixed. A positive shock to the spending function $\left(e_{1}>0\right)$ with $M 1$ fixed raises $Y$, though its effect on $M 2$ is theoretically ambiguous. The higher income tends to raise the quantity demanded of $N T$, the nontransactions component of $M 2$, but the associated increase in the interest rate works in the opposite direction. However, the marked increase since mid-1978 in the proportion of this component bearing market-related yields has substantially lowered its responsiveness to movements in market interest rates (that is, $j$ is approaching zero). Accordingly, it seems clear that the income effect substantially outweighs the interest rate effect and that nominal income and $M 2$ will be positively correlated in response to a shift in spending behavior.

A downward shift in $M 1$ demand $\left(e_{2}<0\right)$ not accommodated by a reduced $M 1$ target will lower the interest rate and raise income. At the same time, both effects serve to increase the quantity demanded of $N T$ (though the interest rate effect is likely small, as noted above). This analysis has relevance for the experience in 1981 when, as discussed below, an apparent downward drift in the shift-adjusted $M 1$ demand function of historical proportions had little impact on $M 2$ velocity.

Sympathetic movements of $Y$ and $M 2$ in response to these disturbances cushion the variability of $M 2$ velocity compared to the situation with an exogenously determined $M 2$. In the latter case, as may be seen in equation 7 , the income numerator in the $M 2$ velocity expression is affected by all three of the equations' errors, but the $M 2$ denominator is, by assumption, unchanged.

The outcome of this analysis is simply that the error properties of M2 velocity predictions depend upon whether M2 is endogenous or held exogenous. Should the Federal Reserve switch to more single-minded control over M2, there is the danger that what appears in recent years to be rather stable and predictable behavior of M2 velocity would tend to break down. ${ }^{11}$

Such a concern is becoming increasingly academic, however, because

11. This analysis provides support for Goodhart's law-that the relation between GNP and a monetary aggregate tends to weaken when the aggregate is brought under controland offers an example of a variant of the Lucas effect. See Robert E. Lucas, Jr., "Econometric Policy Evaluation: A Critique,"' in Karl Brunner and Allan Meltzer, eds., The Phillips Curve and Labor Markets, Carnegie-Rochester Conference Series on Public Policy, vol. 1 (Amsterdam: North-Holland, 1976), pp. 19-46. 
the Federal Reserve's ability to control M2 closely is eroding with each passing phase-down of member bank reserve requirements on personal savings and small time-deposits under provisions of the Monetary Control Act. By March 1984 these requirements will reach zero. Other major nontransactions components of M2-savings and small timedeposits at other institutions, MMMF shares, RPs, and overnight Eurodollars-are even now not reservable.

\section{Money Stock Variability, Money Demand Predictability, and Interest Rates}

The enormous growth in the velocity of shift-adjusted M1 in 1981 is mirrored by a record postsample overprediction of annual growth in this aggregate using the Almon lag money-demand equation in the MPS quarterly model. The relatively long lags built into this equation damp the predicted response of money demand in the current quarter to contemporaneous movements in the independent variables-real income, prices, and interest rates. When M1 is measured to abstract from the effects of nationwide NOWs, money demand grows weakly throughout the year, leading to an overprediction on the order of 6 percentage points for the year as a whole, as shown in the memoranda of table 2 .

The table also reports the remarkably successful annual forecasting record of an alternative equation, which, like the MPS equation, also was fit with data through mid-1974. The success of the Porter-Simpson equation primarily is due to the inclusion of a ratchet type of variable, involving the interest rate on five-year Treasury notes. This variable and its elasticity increase as the current five-year note yield rises above a moving average of its own recent values. ${ }^{12}$ The rationale for the variable is that such an intermediate rate represents the expectations of money holders about short-term rates and therefore the opportunity costs of holding rate-constrained narrow money over a horizon long enough to affect decisions regarding investment in cash-management techniques.

12. Simpson and Porter, "Some Issues." For an analysis of the implications of this equation for the setting and optimal adjustment of the intermediate target for M1 see Lindsey, "Nonborrowed Reserve Targeting." 
Table 2. Actual and Predicted Growth of M1, 1980:1 through 1982:1 ${ }^{\text {a }}$

Percent

\begin{tabular}{|c|c|c|c|c|c|}
\hline \multirow[b]{2}{*}{$\begin{array}{l}\text { Year and } \\
\text { quarter }\end{array}$} & \multirow{2}{*}{$\begin{array}{l}\text { Actual MI } \\
\text { (shift- } \\
\text { adjusted } \\
\text { through } \\
\text { 1981:4) }\end{array}$} & \multicolumn{2}{|c|}{ MPS equation } & \multicolumn{2}{|c|}{ Porter-Simpson equation } \\
\hline & & $\begin{array}{c}\text { Predicted } \\
M I\end{array}$ & Error $^{\mathrm{b}}$ & $\begin{array}{c}\text { Predicted } \\
\quad M 1\end{array}$ & Error $^{\mathrm{b}}$ \\
\hline 1980:1 & 6.2 & 5.4 & 0.8 & 3.0 & 3.2 \\
\hline 1980:2 & -3.7 & 7.2 & -10.9 & 3.5 & -7.2 \\
\hline $1980: 3$ & 13.2 & 9.1 & 4.1 & 7.8 & 5.4 \\
\hline 1980:4 & 10.2 & 6.2 & 4.0 & 9.1 & 1.1 \\
\hline 1981:1 & -0.9 & 6.4 & -7.3 & 6.5 & -7.4 \\
\hline 1981:2 & 5.7 & 8.3 & -2.6 & -3.2 & 8.9 \\
\hline 1981:3 & -0.4 & 7.4 & -7.8 & 2.7 & -3.1 \\
\hline 1981:4 & 4.7 & 9.4 & -4.7 & 6.1 & -1.4 \\
\hline 1982:1 & 10.3 & 5.7 & 4.6 & 0.8 & 9.5 \\
\hline \multicolumn{6}{|l|}{ Memoranda } \\
\hline 1980 & 6.6 & 7.1 & -0.5 & 6.0 & 0.6 \\
\hline 1981 & 2.3 & 8.1 & -5.8 & 3.1 & -0.8 \\
\hline
\end{tabular}

Sources: Board of Governors of the Federal Reserve System and simulations based on the study reported in Memorandum, Edward K. Offenbacher and Richard D. Porter to Michael Prell, "Update and Extensions on Econometric Properties of Selected Monetary Aggregates," Board of Governors, April 7, 1982.

a. At seasonally adjusted annual rates (not compounded).

b. Actual minus predicted.

c. Fourth quarter to fourth quarter.

Increases in this rate above its moving average serve as a proxy for the incentive of money holders to adopt further innovations in cash management. Porter and Simpson's equation implies that the interest elasticity of money demand begins to increase as the yield structure of interest rates moves above a certain point related to past levels. Thus the equation is relatively responsive when interest rates rise to historical highs, as in the second and third quarters of 1981. But existing cashmanagement techniques are assumed to remain in place when intermediate-term interest rates decline below the moving average. In this case the ratchet variable converts to a negative constant, and the interest response of the equation behaves according to the conventional elasticity.

\section{IN TEREST RATES}

The Porter-Simpson equation thus tracks money demand well over 1981 as a whole by adding another economic variable that predicts the 
Table 3. Actual and Predicted Short-Term Interest Rates, 1980:1 through 1982:1

\begin{tabular}{|c|c|c|c|c|c|c|}
\hline \multirow[b]{2}{*}{ Period } & \multicolumn{3}{|c|}{$\begin{array}{l}\text { Porter-Simpson equation (three- } \\
\text { month Treasury bill rate) }\end{array}$} & \multicolumn{3}{|c|}{$\begin{array}{l}\text { St. Louis equation (four-month } \\
\text { commercial paper rate) }\end{array}$} \\
\hline & Actual & Predicted & Error & Actual & Predicted & Error \\
\hline $\begin{array}{l}\text { 1980:1- } \\
\text { 1980:4 } \\
\text { Average }\end{array}$ & 11.4 & 11.0 & 0.4 & 12.5 & 8.2 & 4.3 \\
\hline $\begin{array}{l}\text { 1981:1- } \\
\text { 1982:1 } \\
\text { Average }\end{array}$ & 13.8 & 13.2 & 0.6 & 14.8 & 6.9 & 7.9 \\
\hline
\end{tabular}

Sources: Simulations based on the equations reported in Thomas D. Simpson and Richard D. Porter, "Some Issues Involving the Definition and Interpretation of the Monetary Aggregates," in Federal Reserve Bank of Boston, Controlling Monetary Aggregates III, Conference Series 23 (FRBB, October 1980), pp. 161-234, and "The Quarterly Econometric Model" (Board of Governors of the Federal Reserve System, May 1981).

incentive to adopt improved techniques of cash management. ${ }^{13}$ Its ability to predict average M1 demand over this period suggests the levels of short- and intermediate-term interest rates on average since 1979 have been consistent with the average levels of real income and prices given the quantity of shift-adjusted M1 supplied. To show this result more formally, table 3 displays dynamic simulation predictions of the PorterSimpson equation solved for the three-month Treasury bill rate, using a supplementary term-structure equation to explain the five-year note rate given current and lagged predicted three-month bill rates and current and lagged inflation rates. ${ }^{14}$ Averaged over these periods, the predicted three-month Treasury bill rate is close to the actual rate.

The table also shows simulation results from an alternative model of short-term interest rates, originally constructed by staff at the Federal Reserve Bank of St. Louis. ${ }^{15}$ This equation explains the four-month

13. A full understanding of money-demand behavior in addition requires tracking down the repositories of the displaced money balances-as in the study by Michael Moran and Donald Kohn discussed in the previous section.

14. This term-structure equation is reported in "The Quarterly Econometric Model" (Board of Governors of the Federal Reserve System, May 1981). The sample period for this equation was 1956:4 through 1977:2. In the simulation the add factors to the intercepts of both the Porter-Simpson equation and the term-structure equation were made to eliminate the level errors in 1979:4.

15. See Leonall C. Anderson and Keith M. Carlson, "The St. Louis Model Revisited," International Economic Review, vol. 15 (June 1974), pp. 305-27. For the simulation in this paper, the sample period that began in 1955:1 was extended through 1979:4, using an 
commercial paper rate as related negatively to the current quarter's M1 growth, and positively to current and lagged growth in real GNP and to current and lagged values of the inflation rate scaled by the ratio of the unemployment rate to the full-employment unemployment rate. A dummy variable also is included starting in 1961:1. This equation's large underprediction of the commercial paper rate in the first postsample year rises to nearly 8 percentage points by the last five-quarter period.

Taken together, these results suggest that a money supply-money demand framework better explains the recent determination of shortterm interest rates than a "semireduced form" theory implicitly incorporating adaptive inflationary expectations. Thus, from the perspective of the Porter-Simpson equation, no recourse is needed to ad hoc reasons such as erratic interest rates or variable short-run money growth to explain the high average levels of short-term rates in this period.

\section{QUARTERLY PREDICTIONS}

On a quarterly basis the prediction errors for the Porter-Simpson equation shown in table 2 and the quarterly interest rate errors underlying table 3 were quite large, reinforcing impressions of the sizable residual uncertainty in economists' understanding of short-term variations in money demand. In addition to the impact of the ratchet variable, the equation contains reasonably short lags in response to the other variables, particularly prices, so that the predicted values of M1 growth are more variable from one quarter to the next than those of the MPS equation. However, these variations do not match the actual variation in M1 growth very closely. For example, the weakness in the first quarter and the bulge in the second quarter shift-adjusted M1 in 1981 remains a puzzle from the perspective of this equation. A huge underprediction of quarterly average M1 growth also emerged in the first quarter of 1982, when M1 grew by $10^{1 / 4}$ percent at an annual rate. The Porter-Simpson equation predicted M1 growth of only $3 / 4$ percent.

identical specification. A postsample simulation was then conducted from 1980:1 through 1982:1. As is consistent with the present practice at the Federal Reserve Bank of St. Louis, the equation was simulated with actual rather than shift-adjusted M1 in 1981. Because the equation contains neither a lagged dependent variable nor an autocorrelation correction, the static simulation amounted to a dynamic simulation as well. 
This bulge in M1 growth recorded for the first quarter reflects the more rapid $\mathrm{M} 1$ expansion that began in November of last year, following little change on balance over the previous six months. This strength in M1 demand, despite weakening nominal economic activity, was no doubt partly caused by the conventional lagged effects of interest rate declines during the five preceding months. However, table 4 suggests another important influence, associated with changes in savings motives affecting other checkable deposits. From October through February the average annual growth of OCDs accelerated by about 35 percentage points from the 15 percent pace of the previous six months. This acceleration in OCDs contributed 6 percentage points to the $10^{1 / 4}$ percentage point acceleration of the average annual growth rate of M1 over the four months. A striking feature of the table is the similar behavior of passbook saving flows. After substantial runoffs in the preceding half year, savings rebounded sharply. These patterns are unlike the surge in OCDs early in 1981, which could be attributed to shifts out of savings and demand deposits into NOW accounts that were newly permitted nationwide. ${ }^{16}$ In this recent instance, by contrast, savings deposits exhibited strength rather than weakness, while the runoff of demand deposits nearly ceased.

A plausible partial explanation for the related behavior of OCDs and savings deposits over this four-month period is that the public had temporarily increased its preference for highly liquid assets in response to heightened uncertainties regarding both the economic outlook-as suggested by the higher unemployment rate-and the outlook for interest rates. Some support for this interpretation is provided in the second row of table 4, which shows a remarkably similar pattern for another fourmonth period ending in September 1980. ${ }^{17}$ Taken together, these episodes suggest that the increased importance of OCDs, now representing nearly

16. See the discussion above of the slowdown in growth of the number of new OCD accounts since the initial surge in early 1981 .

17. Since this paper was presented, Flint Brayton of the Board staff discovered that the unemployment rate enters positively and significantly in an econometric model (fit from 1970:1 through 1980:4) designed to explain household passbook savings deposits. In a postsample simulation of his model, the increase in the unemployment rate from 1981:3 to 1982:1 induces a rise in the level of savings deposits of $\$ 12.6$ billion, or 7.2 percent at an annual rate, other things being equal. See Flint Brayton, "Econometric Analysis of the Behavior of Savings Deposits" (Board of Governors of the Federal Reserve System, April 1982). 


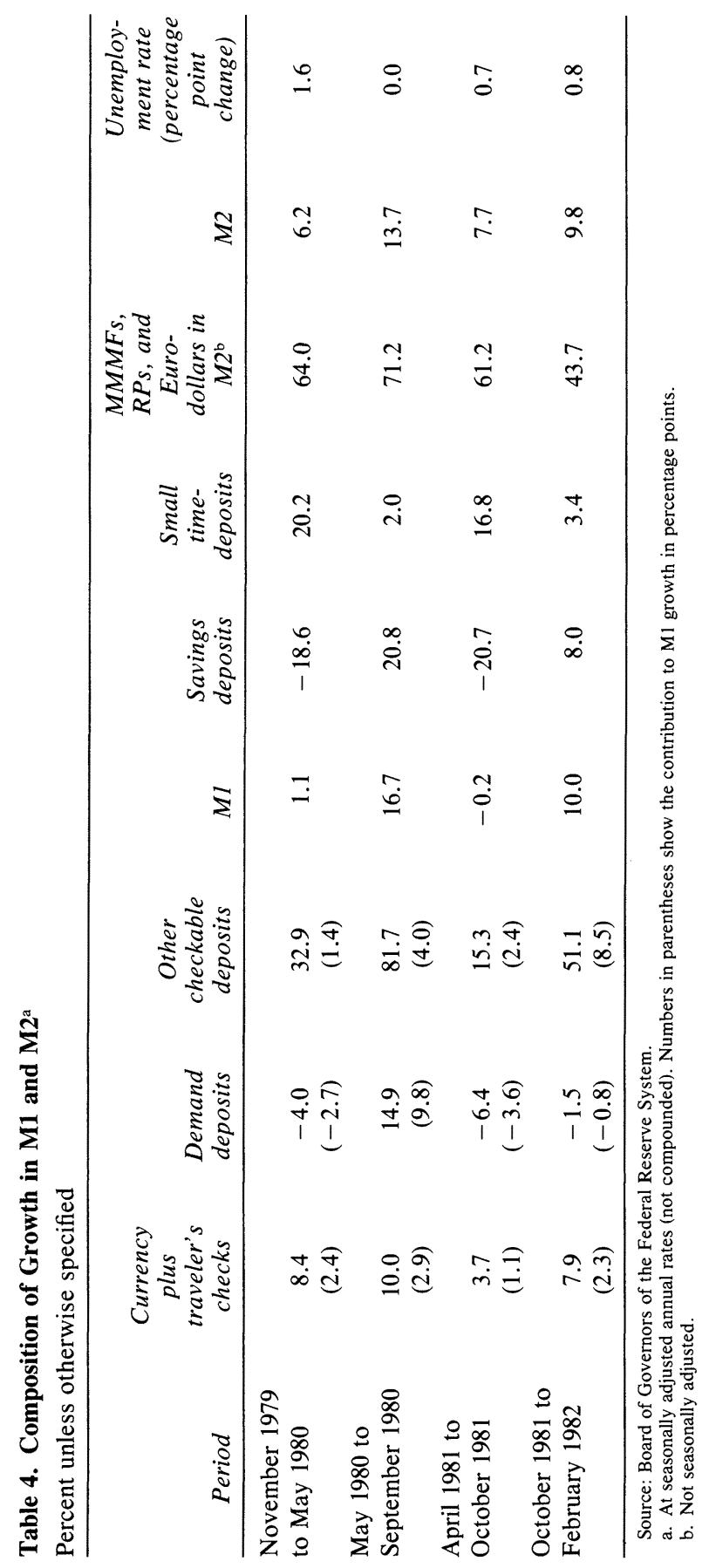


Table 5. Actual and Predicted Growth of M2, 1980:1 through 1982:1 ${ }^{\text {a }}$

Percent

\begin{tabular}{cccr}
\hline & \multicolumn{3}{c}{ Portfolio equation } \\
\cline { 3 - 4 } $\begin{array}{c}\text { Year and } \\
\text { quarter }\end{array}$ & Actual M2 & $\begin{array}{c}\text { Predicted } \\
\text { M2 }\end{array}$ & Error \\
\hline $1980: 1$ & 7.4 & 3.8 & 3.6 \\
$1980: 2$ & 5.2 & 13.1 & -7.9 \\
$1980: 3$ & 14.1 & 6.5 & 7.6 \\
$1980: 4$ & 8.8 & 8.3 & 0.5 \\
$1981: 1$ & 7.5 & 7.6 & -0.1 \\
$1981: 2$ & 12.0 & 7.1 & 4.9 \\
$1981: 3$ & 8.3 & 11.5 & -3.2 \\
$1981: 4$ & 8.9 & 12.9 & -4.0 \\
$1982: 1$ & 9.7 & 7.3 & 2.4 \\
Memoranda & & & \\
1980 & 9.2 & 8.2 & 1.0 \\
1981 & 9.5 & 10.2 & -0.7 \\
\hline
\end{tabular}

Source: Same as table 2 .

a. At seasonally adjusted annual rates (not compounded).

b. Fourth quarter to fourth quarter.

one-fifth of M1, has made savings-oriented motives a more important influence on M1 demand than they have been in the past. Thus M1 demand in the future could respond differently to movements in economic variables than it has historically.

Table 5 shows the quarterly behavior of M2 demand relative to predictions from a portfolio equation in which interest rates and wealth determine M2. The quarterly movements in this aggregate were not much more predictable than were those of M1 during this period. Focusing on the most recent quarter, the $93 / 4$ percent M2 growth in 1982:1 was somewhat above the equation's forecast. This expansion put M2, along with M1, above the upper bound of the FOMC's annual range by March.

INTEREST RATES AND MONETARY TARGETS

With nonborrowed reserves as the operating target for monetary policy, a pickup to above-target growth in the monetary aggregates, as in 1982:1, automatically tightens the reserve positions of banks as required reserves rise relative to nonborrowed reserves. The federal 
funds rate and other short-term market rates tend to move up. This response pattern of short-term rates to stronger or weaker money growth has consistently marked the period since the inception of the Federal Reserve's new operating procedures in October 1979. (Intermediateand long-term interest rates are affected by short-term rates, but are strongly influenced by other factors as well. This was apparent last summer when very short-term rates receded while long-term rates, following passage of the tax cut, continued their upward march.)

Such behavior of short-term rates is predicted by a theory of moneystock determination when the money-demand schedule (on interest ratemoney space) is subject to greater variation than the money-supply schedule, and when money-supply and money-demand functions have, respectively, positive and negative short-term interest rate elasticities. In this situation, the Federal Reserve's procedures partially accommodate short-run divergences in money demand from target. At the same time, as changed short-rates alter the quantity of money demanded, forces automatically start to bring money partially back to target. Over the longer run of three to six months, the Federal Reserve also tends to adjust the path for nonborrowed reserves and the discount rate, as may be needed, to bring the monetary aggregates fully back to path.

This description of the process through which the money supply is controlled, combined with the expectations hypothesis of the term structure of interest rates and the efficient markets hypothesis, explains why publication of an unexpectedly strong M1 figure after the close of the business day on Friday raises interest rates across the maturity spectrum in after-hours trading. Market participants know, perhaps only intuitively, that surprise in money demand in a given week calls for some revision in the same direction in their expectations of the money-demand schedule in future weeks also. Over the near term, if money demand is surprisingly high, the expected level of the federal funds rate will be higher than previously thought because of the enlarged levels of discount borrowing implied by a fixed nonborrowed reserves operating target and higher expected required reserves. Expectations of short-term interest rates over a longer period also will be raised if participants believe the Federal Reserve will, in three to six months, provide only an amount of reserves able to support a stock of money consistent with the long-run money objective. Future short-term rates higher than previously expected would be needed to bring the quantity of money demanded in 
line, given the higher forecasts of future money-demand schedules. Accordingly, interest rates with maturities of six months to a year can also be expected to rise in line with the higher expectations for future shorter-term spot rates.

The response of Treasury bill rates with these maturities to Friday publication of the money stock has been substantially greater since October 1979 than before. ${ }^{18}$ This behavior suggests that the Federal Reserve's determination to control annual money growth became more credible to market participants after the institution of the new procedures. My impression, however, is that long-term interest rates typically have adjusted by more than is consistent with this mechanism alone in the context of an expectations hypothesis of the term structure. In general, not only Treasury bill rates but also bond yields have exhibited considerable variation over the last two and one-half years, and standard economic theories do not seem to provide a convincing explanation. For these long-term rates, it appears that a puzzle still remains.

\section{The Optimal Precision of Short-Run Monetary Control}

Financial innovations and instabilities of money demand in recent years have led some to ask whether the Federal Reserve should replace monetary aggregates with other variables as primary intermediate targets or, indeed, whether it should not resort to intermediate targets at all. I believe monetary aggregates can be oversold as intermediate targets. However, I also believe that, used flexibly, they offer a better guide to monetary policy than any alternative approach. Assuming that discre-

18. See William Conrad, "Treasury Bill Market Response to Money Stock Announcements" (Board of Governors of the Federal Reserve System, January 1981). Conrad regressed the change in Treasury bill rates from the Friday closing to the Monday opening on the published weekly change in the demand deposit component of M1. (This independent variable, rather than the change in M1 itself, was used as a proxy for the unexpected change in M1 because certain currency data is released a week earlier. He also tried using the residuals from time-series equations, but with less success.) The coefficients for the twelve-month period before October 1979 were uniformly smaller and less significant statistically than for the twelve-month period following October 1979. The coefficients jumped from generally less than 1 basis point per $\$ 1$ billion change in demand deposits to a range of 3.7 to 6.7 basis points for the four maturities of less than one year that he examined. 
tionary adjustments of the targets, and even of the definitions of the monetary aggregates, are made in response to documented shifts in demand functions and emerging financial innovations, monetary aggregates afford the most reliable form of discipline for discouraging both a procyclical bias and a long-run inflationary bias in the conduct of monetary policy. A gradual slowing of the trend growth of the (adjusted) aggregates over time can assure a permanent end to systematic inflation, which in turn is a precondition for more sustainable real economic growth than was observed in the 1970s. ${ }^{19}$

Even if this general case for targeting aggregates is accepted, how closely monetary aggregates should be kept to their long-run path over short periods is a separate question that raises a different set of issues. During the past several years considerable research effort has been devoted to determining how closely the Federal Reserve could control the money supply in the short run and what changes in institutional arrangements could improve that control. By now this work, both inside and outside the Federal Reserve, has provided adequate answers, and, in most cases, reasonably precise empirical estimates of relevant magnitudes. ${ }^{20}$ It seems clear that, even under present regulations and the existing framework of operating procedures, the Federal Reserve could have kept M1, say, somewhat closer to the midpoint of its longer-run range than it has and, with changes in regulations and operating procedures, could have reduced even further the size of short-run divergences from target.

However, the more fundamental question is whether the Federal Reserve should tighten its control mechanism and resist more forcefully and promptly any short-run deviations of money from the midpoint of its target range. The general targeting approach can be viewed as the

19. A separate paper would be required to complete this Churchillian defense of monetary aggregates by recounting the relative disadvantages of nominal or real interest rates, credit aggregates, nominal or real GNP or the price level as intermediate targets, or of dispensing with intermediate targets altogether.

20. For a sample of this research see David Lindsey and others, "Monetary Control Experience under the New Operating Procedures," in Federal Reserve Staff, New Monetary Control Procedures, vol. 2 (Board of Governors of the Federal Reserve System, February 1981), and Peter Tinsley and others, "Policy Robustness: Specification and Simulation of Monthly Money Market Model," presented at the Conference on Current Issues in the Conduct of U.S. Monetary Policy, American Enterprise Institute, February $4-5,1982$. 
successive determination of long-run goals for ultimate targets, such as GNP, prices, or unemployment; of long-run objectives for the intermediate targets, such as a monetary aggregate; of short-run objectives for the intermediate targets; and of short-run settings for the operating instruments, such as some form of reserves. The short-run control issue involves the last two of these steps and can be usefully addressed by three subquestions:21

How far should regulatory and procedural reforms go in enhancing the short-run predictability of the money-supply function implied by the reserve operating target?

How far should regulatory and procedural reforms go in reducing the short-run interest elasticity of this money-supply function?

How quickly should the Federal Reserve attempt to return the money stock to its long-run objective following divergences? ${ }^{22}$

In response to these three questions, single-minded advocates of the tightest possible control of the money stock would answer "very far, very far, and very fast." On technical grounds, and given their first objective of reducing disturbances to the supply function, they could justifiably recommend a package of contemporaneous, uniform, and universal reserve requirements on the components of the aggregate being controlled. Moreover, a switch from a nonborrowed to a total reserves operating target would substantially reduce the interest elasticity of the

21. As noted, arguments have been made for dispensing with the two middle steps; this approach would adjust the operating instruments in response to direct and inferential information about the ultimate targets. While data on all intermediate variables would provide such inferential information, no intermediate variable would be interpreted as a surrogate target. See, for example, Ralph C. Bryant, Money and Monetary Policy in Interdependent Nations (Brookings Institution, 1980).

22. How far regulatory changes should go in fostering an environment that facilitates selection of the appropriate definition and growth rate for the long-run monetary objective is a related question that has been discussed in detail elsewhere. For example, see James L. Pierce, "How Regulations Affect Monetary Control," and David E. Lindsey, "Comment," both presented at the Conference on Current Issues in the Conduct of U.S. Monetary Policy, American Enterprise Institute, February 4-5, 1982. Removal of deposit interest rate ceilings or prohibitions and payment of a market-related interest rate on required reserves certainly would help. However, as Donald Kohn has cautioned, such reforms would eliminate the incentive for financial intermediaries to offer separate accounts that segregate transactions and savings balances if at the same time they fully unbundled service charges for check clearing and account maintenance from rates paid. A measure of transactions balances would then invariably be contaminated by a significant savings component. 
money-supply relation. (A monetary base operating target would produce the same result, but would also involve a less predictable supply function in the presence of the other reforms, owing to the greater importance of unexpected disturbances to currency demand.) To minimize unpredictable changes in discount borrowing, which require offsetting open market operations with a total reserves operating target, such advocates could favor a floating penalty discount rate. This step, by aiding day-to-day control over total reserves, would impart a little more predictability to the money-supply function..$^{23}$

Should policymakers heed all this advice and aim for tightest possible control of money? It would be desirable to establish a predictable moneysupply function by having contemporaneous, uniform, and universal reserve requirements on transactions balances, regardless of issuer, and arbitrage restrictions. Such reforms would reduce the size of disturbances in the money-supply function that alter interest rates and displace ances in the money-supply function that alter interest rates and displace the money stock from the target, given nonborrowed reserves. To be sure, the present practice of making judgmental adjustments to reserve paths between FOMC meetings in response to new information about such disturbances serves the same purpose. Even so, the process of reserve targeting would be simplified by such reforms, and some improvement in monetary control may result from minimizing in the first place the occurrence of disturbances requiring such defensive reactions.

On the other hand, there is a strong case against going "much farther or faster than now" in reducing the interest elasticity of the short-run money-supply function or aiming for a faster return of money to the long-run objective when money departs from that objective. It rests on interpreting the positive association between movements in short-term interest rates and M1 that has been observed since October 1979 as arising largely from variations in the demand schedule for M1. Present procedures accommodate some of these variations on the presumption

23. Certain other changes that have been proposed by monetarists are inconsistent with the objective of the tightest possible short-run monetary control. For example, Milton Friedman's support for staggered reserve accounting and a predetermined path over intervals of several months for open market operations would reduce the short-run predictability of the money-supply function. Friedman apparently is willing to sacrifice some degree of short-run control in order to reduce the scope for discretion on the part of the central bank. See Milton Friedman, "Monetary Policy: Theory and Practice," Journal of Money, Credit and Banking, vol. 14 (February 1982), pp. 98-118. 
that, first, such short-run deviations in money from path do not significantly disturb the economy; and second, a steeper short-run supply function coupled with greater determination to keep it coincident with the long-run money path at all times would add significantly to volatility in credit markets.

In light of these considerations, a target for nonborrowed reserves is preferable to a total-reserve operating target, and a nonvertical discount rate graduation is preferable to a floating penalty discount rate. Furthermore, when a gap between the money stock and the midpoint of the longer-run range opens up in a given month, the Federal Reserve should not aim at closing it in less than three months or so on average. And as noted above, policymakers should keep the option of adjusting the longrun monetary target in response to reasonably conclusive indications of permanent shifts in the money-demand function.

Some economists have argued for a much tighter short-run control of the money supply by offering an alternative interpretation of recent interest rate movements. In their interpretation, short-term interest rates respond positively to that portion of money-stock variations perceived as permanent by market participants. ${ }^{24}$ Economic agents see such permanent monetary impulses as having future consequences for spending, credit demands, rate of change of prices, and hence interest rates. Thus a policy that would lessen variation in money and total reservesand in turn lower market participants' perceptions of variations in the permanent component of money and reserve shocks-would reduce, not increase, the volatility of short-term interest rates.

However, there seem to be several problems with this analysis. Given the lags in the transmission mechanism linking changes in money and total reserves to economic activity and prices, it is difficult to believe that changes in perceptions of the permanent component of money and reserves should affect interest rates on assets with maturities as short as three to six months. Furthermore, it is hard to see why a sizable part of weekly changes in money should be expected to be permanent, let alone why they should be expected to modify the longer-run growth rate of

24. See, for example, Shadow Open Market Committee, "Policy Statement," (University of Rochester, Center for Research in Government Policy and Business, Graduate School of Management, March 1982), and Karl Brunner and Allan H. Meltzer, "Strategies and Tactics for Monetary Control," prepared for the Carnegie-Rochester Conference on Public Policy, University of Rochester, April 1982. 
money. Finally, the changes in the Federal Reserve's policy that led to a stronger commitment to meet longer-term targets for money growth should have reduced the perceived permanence of short-term variations in money; yet interest rate volatility increased after the new policy was adopted.

The arguments for tight short-run control of the money stock are not supported by an empirical model that can explain short-term interest rate and money-stock movements as well as the conventional moneysupply, money-demand framework..$^{25}$ Unless a convincing alternative to the money supply-money demand framework is developed and tested, policymakers should be wary of controlling the stock of money over monthly and even quarterly periods with the precision that is technically feasible.

Determining the appropriate degree of short-run accommodation to money-demand shifts remains difficult. The answer depends on the dynamic response of the financial sector and economic activity to changes in the reserves instrument and to shocks to money-supply and money-demand functions, as well as on the nature and persistence of those shocks. Despite several laudable studies, economists' understanding of what dynamic properties the monetary aggregates and the economy would display under alternative monetary control procedures remains limited. ${ }^{26}$ Thus there is considerable room for additional research on these, and related, topics.

25. Even though subject to sizable errors in its money-demand equation, the Board's monthly money market model in one test covering 1980 yielded better postsample forecasts of multipliers relating $\mathrm{M} 1$ to reserves or to the monetary base than an alternative timeseries model proposed by James M. Johannes and Robert H. Rasche. (The results for the nonborrowed reserve and nonborrowed base measures and for M2 multipliers were not greatly different, however. See Lindsey and others, "Monetary Control Experience," table 4.) The Johannes-Rasche model does not predict interest rates. But see the earlier discussion of short-term interest rate forecasts of the St. Louis equation showing that very large errors were implied in recent quarters.

26. See John H. Ciccolo, "Is Short-Run Monetary Control Feasible?" in Federal Reserve Bank of New York, Monetary Aggregates and Monetary Policy (FRBNY, 1974), pp. 82-91; Peter A. Tinsley and others, "Money Market Impacts of Alternative Operating Procedures," and Jared Enzler and Lewis Johnson, "Cycles Resulting from Money Stock Targeting," both in New Monetary Control Procedures, vols. 2 and 1, respectively. 


\section{Discussion}

Much of the discussion was devoted to controversy about what quantity, price, or interest rate the Federal Reserve ought to select as its target. Robert J. Gordon argued that the monetary authorities ought to establish targets in terms of nominal GNP rather than monetary aggregates. Gordon noted the difficulties in selecting a particular monetary aggregate to control and argued that when the relation between the aggregate measure and GNP changes, it takes authorities too long to respond to the change. He advocated targeting a two- or three-quarter moving average of nominal final sales, with monetary policy being changed as final sales deviate from their target path. Albert Wojnilower suggested that the Federal Reserve has implicitly used nominal GNP as its target for many years. However, the policy has been unannounced because an explicit nominal GNP target is not politically feasible. Announcing a GNP target comes close to announcing an unemployment rate-and one that is often unacceptable-whereas a monetary target implies no precise unemployment level because of the variability in velocity. Thus while the Federal Reserve has a nominal GNP target in mind when it announces its money targets, there is no politically embarrassing admission of an associated unemployment rate.

A number of discussants suggested that the old regime of interest rate targeting looks better now that we have had experience with moneysupply targeting. Lawrence Klein argued that the interest rate and the growth rate of M1B have fluctuated much more widely since the introduction of money-supply targeting in October 1979. He inferred that the new rule has introduced far more instability into the system than was present under the old operating procedures. Christopher Sims addressed the issue of whether the Federal Reserve should further tighten its monetary control mechanisms and resist more forcefully short-run deviations from the target. He noted that myopic attempts to eliminate all deviation in monetary aggregates from targets in the short run could, ironically, result in greater instability in both the instrument and the target. According to his own econometric investigations, it appears that the relation between money stock and interest rates is 
consistent with the instability described by Klein. Lindsey cautioned that the absolute errors of standard money-demand functions had risen substantially in the past two years, suggesting that the greater instability of both interest rates and the money stock could be independent of the change in operating procedures. Ralph Bryant noted that the focus of policy on intermediate monetary targets, regardless of the particular aggregates selected, could easily have undesired consequences. $\mathrm{He}$ argued that the current specification of ranges for the monetary targets gave the Federal Reserve more flexibility than its own rhetoric might suggest. But Bryant concluded that the monetary authorities are nonetheless more rigid in their commitment to the monetary targets than they ought to be in view of the instability of velocity and of the "multiplier" linking money to bank reserves.

Alan Blinder reasoned that a decade ago our knowledge about the relations between the relevant variables was too sketchy to permit a choice between interest rate targeting and targeting the money supply. However, the progressive deregulation of the financial system that will occur over the next few years now clearly makes interest rate targeting preferable to the monetarist prescription. Gordon added that in a world of uncertain money demand, interest rate targeting is probably the best way to implement a nominal GNP target over the next couple of years.

John Kareken took issue with the proponents of interest rate targeting. He suggested that the mentality of the Federal Open Market Committee was the principal reason for preferring money-supply targets to interest rate targets because the committee would never permit interest rates to move as much as appropriate countercyclical policy required. Franco Modigliani argued for targeting monetary aggregates, interest rates, and GNP. When realizations of these variables are not consistent with targets or are not consistent with one another, policymakers should attempt to decide why and then alter the targets appropriately.

Two hypotheses were offered to explain the market reaction to the "surprises" in Friday announcements of money-supply growth. Wojnilower rejected the notion that large fluctuations in interest rates following these announcements could be attributable to any kind of sober expectations process concerning the longer-term impact of money surprises. He offered instead the view that bond traders and participants in futures markets are engaged in a speculative game with short timehorizons in which key macroeconomic variables play no real role. Jeffrey 
Sachs agreed with Lindsey's interpretation of money surprises and offered some supporting evidence from the foreign exchange market. Under the hypothesis that surprisingly high money growth is associated with higher expected rates of future inflation, unexpected fast money growth would be associated with depreciation of the dollar. By contrast, under the hypothesis that such surprises are indicative of shifts in money demand, as Lindsey suggests, they would be associated with a strengthening of the dollar. He reported that results of Jeffrey Frankel's research support the second hypothesis.

William Poole disagreed with two technical points raised by Lindsey's paper. First, he took issue with Lindsey's conclusion that the shift into M1 due to introduction of NOW accounts is over. Pointing to the New England experience, he argued that this shift is likely to take much longer to complete. Lindsey responded that the promotional activities of depository institutions were relatively prompt and intense this time, so the national shift ought to run its course faster. Poole also disagreed that Federal Reserve policies are best characterized as nonborrowed reserves control. He argued that Federal Reserve policy is better characterized as free reserves control. If the Lindsey characterization were correct, the monetary authorities would not have to take a position on how quickly to bring money growth back to the target path but would, instead, allow the market to make that decision through bank decisions at the discount window or through their decisions on holding borrowed or excess reserves. 